\title{
Prevalence of common gastro-intestinal nematode infections in commercial goat farms in Central Uganda
}

\author{
G. Nsereko ${ }^{1}$, P. Emudong ${ }^{1}$, H. Mulindwa ${ }^{1}$ and J. Okwee-Acai ${ }^{2}$
}

\author{
${ }^{1}$ National Animal Resources Research Institute (NaLIRRI), P. O. Box 96, Tororo, Uganda \\ ${ }^{2}$ Department of Pharmacy, Clinical and Comparative Medicine, School of Veterinary Medicine \\ and Animal Resources, P. O. Box 7062, Kampala, Uganda
}

Author for correspondence: jokwee@ covab.mak.ac.ug, jokwee@yahoo.co.uk

\begin{abstract}
Gastro-intestinal nematode (GIN) infections are the leading cause of production losses in commercial goat farms worldwide. This study determined the level of gastro-intestinal nematodes (GIN) infection and identified the common GIN parasites in commercial goat production in Central Uganda. Faecal egg counts and morphological larval identification in coprocultures were used to estimate the burden of common GIN of goats in Central Uganda. Egg shedding was detected in $43 \%$ of the goats. Worm burdens were highest $(498-713 \mathrm{epg})$ in goats 3-5 and 8-9 months old. Goats of 6-8 and older than 9 months showed relatively lower egg counts (254491epg). Haemonchus (56\%), Oesophagostomum (33\%) and strongyloides species (11\%) were the only nematode species identified on coprocultures.
\end{abstract}

Key words: Gastro-intestinal nematode, Haemonchus species, Oesophagostomum, worms

\section{Introduction}

Gastro-intestinal nematode (GIN) infections are the leading cause of production losses in commercial goat farms worldwide (Nganga et al., 2004). Nematode infections suppress weight gain, reduce reproductive efficiency and cause high mortality, especially of kids (Waller, 2006; Lashari and Tasawar, 2011). Consequently, the control of GIN, usually by means of routine anthelmintic application constitutes nearly $60 \%$ of the cost of inputs on commercial goat farms (Vatta et al., 2004).

Trychostrongyloid nematodes that parasitise the abomasum and the intestines, especially the 'barber pole worm,' Haemonchus contortus, are the commonest and most devastating in commercial goat farming in sub-Saharan Africa (Kusiluka and Kambarage, 2006). A survey in Uganda by Magona and Musisi, 1999 revealed a significantly high 
prevalence $(73.3 \%)$ of haemonchosis in goats. Most GIN infections, especially in indigenous goats are subclinical, causing production losses that may not be easily noticed by farmers (Kusiluka and Kambarage, 2006). However, high haemonchosis-associated mortalities have been reported in boar goat kids in Uganda (Okwee-Acai et al., 2010).

Effective control of GIN infections is essential for maximising profitability in commercial goat farming. This requires routine epidemiologic monitoring, to ascertain the common worm types, the levels of infection (prevalence/incidence) and the clinical effects in goat populations (Waller, 2006). This, in turn, helps in formulating a suitable strategic worm control programme. Unfortunately, livestock helminth surveillance is not routine in Uganda, hence, current information necessary for clinical and diseases control decision making is absent.

This study aimed at determining the level of GIN infection in goats and identifying the common GIN parasites on selected commercial goat farms in Central Uganda.

\section{Materials and methods}

\section{Study animals}

Faecal samples were collected from goats in three commercial farms in Gomba District, Central Uganda, that had reported high cases of kid mortality suspected to be due to GIN infections. Faecal samples were collected from all male and female goats aged between 3-12 months. All the farms had no paddocks (open grazing system), with goats (all ages) grazing on natural grass pastures and shrubs. All the goats had a history of no anthelmintic treatment six weeks prior to sampling.

\section{Collection and handling of faecal samples}

Using a gloved index finger, faeces were scooped from the rectum with a goat restrained in standing position. Faecal samples were collected between 9 - 10 a.m. from the holding pens, before the goats were released to graze. Each sample was placed in a separate polythene bag, labeled and put in a cool box containing ice-blocks (about $0^{\circ} \mathrm{C}$ ) for transportation to the laboratory. Laboratory analysis was done on the day of collection.

\section{Faecal egg evaluation}

Identification of nematode eggs was done using the standard salt flotation technique (Hansen and Perry, 1994). Furthermore, nematode egg counting per gramme of faeces (epg) was done on the same samples using the modified McMaster technique, as described by Hansen and Perry (1994).

\section{Identification of third stage nematode larvae}

About three grammes of faeces were taken from each sample. These were mixed with sterilised cow dung in a porcelain pestle containing about $5 \mathrm{ml}$ of water and gently stirred with a motor. The mixed sample was then cultured at $27^{\circ} \mathrm{C}$ for seven days. Using the Baermann technique as described by the Manual of Veterinary Parasitological techniques of the Ministry of Agriculture, Fisheries and Food, United Kingdom (MAFF, 1986). The third stage nematode larvae $\left(\mathrm{L}_{3}\right)$ were recovered from the coprocultures and examined at $x 5$ objective of a light microscope (Zeiss®, West Germany). 


\section{Statistical analysis}

Data were subjected to statistical analysis using the SAS Programme (2010 version). A general linear model (GLM) was used to test for the association between egg counts and the farms, breed, age and sex of goats

\section{Results}

\section{Prevalence of GIN infections}

Of the 470 goats examined $43 \%$ had nematode eggs. Prevalence per farm was 32,56 and $45 \%$ for farms 1,2 and 3, respectively (Table 1).

\section{Faecal egg counts}

Egg counts (epg) for the three farms are presented in Figure 1. As illustrated in
Table 2, mean faecal egg counts in male goats (420 epg) was higher than in females (392 epg), though the difference was not statistically significant $(\mathrm{t}=0.51, \mathrm{P}=0.61)$. Mean faecal egg counts were also higher in indigenous goats (414 epg) than in Boer crosses (398 epg), but again the difference was not significant $(\mathrm{t}=0.32, \mathrm{P}=0.75)$.

\section{Age of goats}

The egg count was 498 epg in goats of three months of age, this steadily declined to the least mean egg count of $254 \mathrm{epg}$ in goats of six months old. In goats older than 6 months, the egg counts rose with age, peaking at epg of 713 epg in 9-month old goats, then subsequently declining. From the coproculture, 72 nematode larvae were recovered and identified as $40(56 \%)$

Table 1. Prevalence of gastro-intestinal nematode parasites in goats in Central Uganda

\begin{tabular}{lcccc}
\hline Farm location & Farm & Goats examined & $\begin{array}{c}\text { Goats shedding } \\
\text { fecal eggs }\end{array}$ & $\begin{array}{c}\text { Prevalence } \\
(\%)\end{array}$ \\
\hline Maddu sub-county & 1 & 207 & 67 & 32 \\
Maddu sub-county & 2 & 120 & 68 & 56 \\
Kabulasoke sub-county & 3 & 143 & 65 & 45 \\
Total & & 470 & 200 & 43 \\
\hline
\end{tabular}

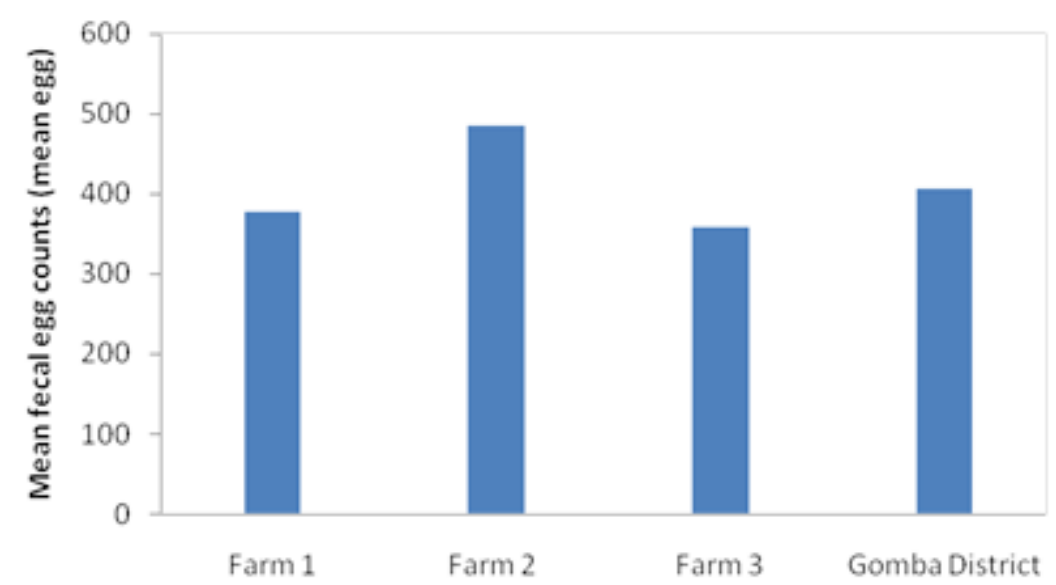

Figure 1. Mean faecal egg counts (epg) in goats in Gomba District in Central Uganda. 
Table 2. Faecal egg counts by sex and breed of goats in Gomba in Central Uganda

\begin{tabular}{llccc}
\hline Attribute & Sex & Mean egg count (epg) & t- statistic & P- value \\
\hline Sex & Male & 420 & - & - \\
& Female & 392 & 0.51 & 0.61 \\
\multirow{2}{*}{ Breed } & Boercross & 398 & - & - \\
& Indigenous & 414 & 0.32 & 0.75 \\
\hline
\end{tabular}

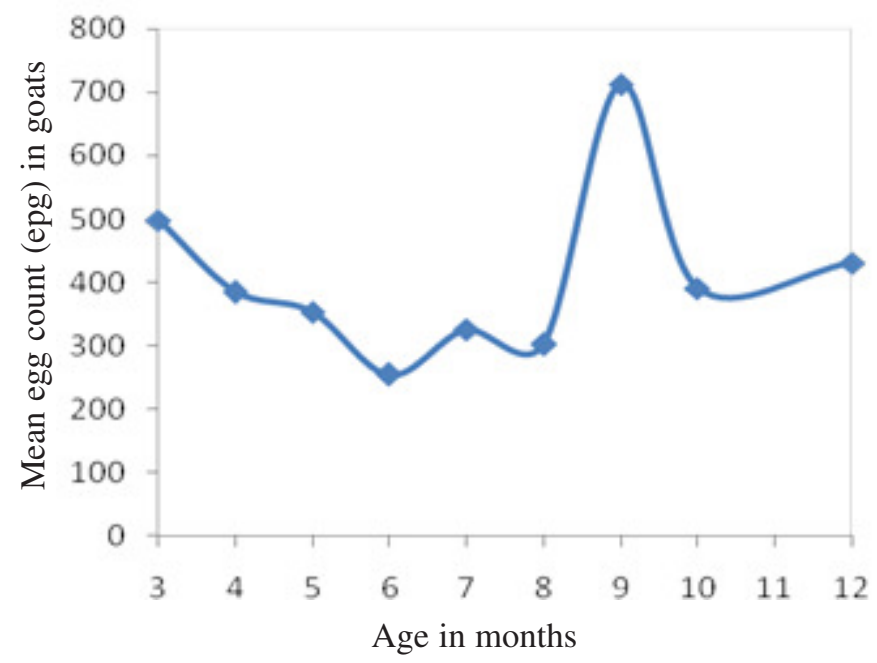

Figure 2. Mean faecal egg counts according to age of goats in Gomba in Central Uganda.

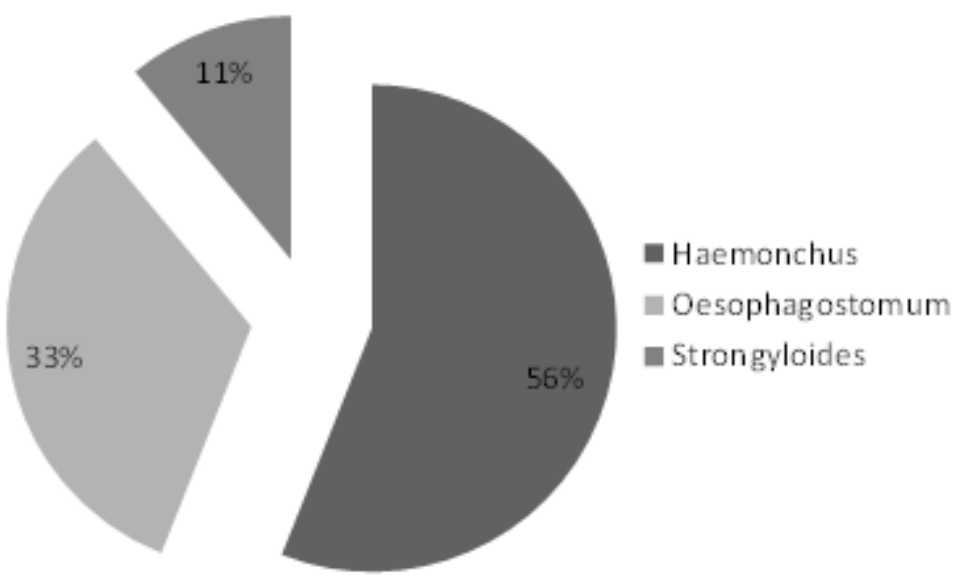

Figure 3. Nematode species in goat coprocultures in Gomba in Central Uganda. 
Prevalence of common gastro-intestinal nematode infections

Table 3. Faecal egg counts according to age of goats in Gomba in Central Uganda

\begin{tabular}{lcccc}
\hline Age (months) & Mean egg count (epg) & Age comparison & t-statistic & p-value \\
\hline 3 & 498 & & - & - \\
4 & 385 & 3 versus 4 & 1.39 & 0.17 \\
5 & 353 & 3 versus 5 & 1.69 & 0.09 \\
6 & 254 & 3 versus 6 & 2.69 & $0.008^{*}$ \\
7 & 326 & 3 versus 7 & 1.85 & 0.068 \\
8 & 302 & 3 versus 8 & 2.23 & $0.023^{*}$ \\
9 & 713 & 3 versus 9 & 1.77 & 0.080 \\
10 & 391 & 3 versus 10 & 0.82 & 0.41 \\
12 & 431 & 3 versus 12 & 0.86 & 0.39 \\
\hline
\end{tabular}

*Significantly $(\mathrm{p}<0.05)$ low epg compared to goats aged three month old

Haemonchus species, $24(33 \%)$ Oesophagostomum and $8(11 \%)$ Strongyloidesspecies (Fig. 3).

\section{Discussion}

Up to $43 \%$ of goats shed nematode eggs at the time of data collection. This was a low prevalence compared to $53.7 \%$ reported earlier by Magona and Musisi (1999) in tethered village goats in Mbale District in eastern Uganda. In Kenya, Meingi et al. (2001) reported a much higher GIN prevalence $(62 \%)$. The most plausible explanation for the observed low nematode prevalence in this study is that the goats were in a free-range grazing system. Free-ranging goats cause lower worm burdens than tethering them. This is attributed to the fact that goats are naturally browsers, hence, prefer to pick leaves high above the ground (Davis, 1996).

Tethered goats, on the other hand, are confined, hence eat the little available vegetation usually to the ground. This leads to increased likelihood of picking nematode larvae. In Gomba District, the goats were on free-ranged in large open pastures covered by woody vegetation and shrubs; hence, limiting the likelihood of heavy pasture contamination by nematode larvae. Furthermore, browsing on shrubs tends to lower GIN burdens in goats by reducing the intake of infective larvae from pastures close to the ground (Kabasa et al., 2000). Some browse plants also contain substantial amounts of crude protein and condensed tannins, that enhance nutrition and ability of the animal to resist GIN (Chandel and Mehta, 1990; Kabasa et al., 2000). Tethering, on the other hand, encourages continuous picking of worm larvae from the contaminated vegetation, where a tethered goat is confined.

It is, therefore, advisable that farmers, preserve browse plants such as acacia species in goat farms, as a strategy for controlling helminthosis.

In this study, the faecal egg counts in Boer crosses were comparable with those of indigenous goats (Table 2). This contradicts earlier reports that indigenous East African goat and sheep breeds are more tolerant to worms than the exotic South African Boer goat or its crosses (Baker et al., 2003; Kusiluka and Kambarage, 2006; Okwee-Acai et al., 2010).Worm infestation may, hence, not be a serious threat to cross breeding as a strategy for genetic improvement of 
indigenous Ugandan goats. It should, however, be noted that pure indigenous goats in the current study were too few compared to the Boer goat grosses to make these results more conclusive.

Infection rate was higher in the young compared with older goats (Table 3 ). A similar result was reported in sheep in Kajiado District in Kenya (Nganga et al., 2004). Generally, young animals are more susceptible to nematode parasite infections. The older animals have better developed immunity against nematode infections (Tasawar et al., 2010). Strategic deworming of goats may, hence, be aimed at young ones, usually targeting those at three or so months. There was, however, a significant rise in egg counts in goats between 8-9 months old. No clear explanation for this exists, but again this could be another target point in strategic deworming of goats. Furthermore, given that 8-9 months is about the age of puberty in goats, the relationship between resistance to worms and the onset of puberty or changes in sex hormones in goats should be established. It is, however, apparent from these results that farmers may de-worm young goats (3-5 months) and the juvenile (8-9 months) because of their apparent increased vulnerability to GIN infections compared to other age groups.

The most prevalent nematode in all the farms was Haemonchus species (Table 1). This agrees with other studies in the tropics (Nganga et al., 2004; Akhter et al., 2011). Haemonchosis is the most predominant nematode in goats in subSaharan Africa (Kusiluka and Kambarage, 2006). The possible explanation for the predominance of Haemonchus nematode parasites lay in the fact that they have a high biotic potential, such that they can establish very rapidly as long as the temperature and moisture conditions that favour their survival are present. Other nematodes such as Trichostrongylus species have a lower biotic potential and, hence, their establishment is slower. Even in mixed infections, Haemonchus easily outcompete other nematode species and becomes predominant (Magona and Musisi, 1999).

Though Haemonchus is usually the dominant parasite, field infections of gastro-enteritis in small ruminants are due to the additive pathogenic effects of several nematodes, with differences in predilection sites and pathogenetic mechanisms (Kusiluka and Kambarage, 2006; Akhter et al., 2011). A control strategy such as vaccination, aimed at Haemonchosis, could greatly reduce the burden and cost of Helminth control in Central Uganda.

\section{Conclusion}

There is a relatively low burden of helminthosis in goats on commercial farms in Central Uganda. Worm burdens are highest in goats 3-4 months and those 8-9 months old; hence, strategic de-worming could be aimed at those age categories. Control measures such as vaccination should be aimed specifically at Haemonchus.

\section{Acknowledgment}

The National Agricultural Research Organization (NARO), Uganda funded this research. We also thank colleagues at the National Livestock Resources Research Institute (NaLIRRI), Tororo for their technical support and advice. 


\section{References}

Akhter, N., Arijo, A.G.,Phulan, M.S., Iqbal, Z. and Milbhar, K.B. 2011. Prevalence of gastrointestinal nematodes inn goats in Hyderabad and Adjoining areas. Pakistan Veterinary Journal 31(4):287-290.

Baker, R.L., Nagda, S., Rodriguez-Zas, S.L., Southey, B.R., Audho, J.O. Aduda, E.O. and Thorpe, W. 2003. Resistance and resilience to gastrointestinal nematode parasites andrelationships with productivity of Red Maasai, Dorper and Red Maasai' Dorper crossbred lambs in the sub-humid tropics. British Society of Animal Science 76:119-136.

Chandel, J.S. and Mehta P.K. 1990. Nematicidal properties of leaf extract of wild sage (Lantana camara). Indian Journal of Agricultural Science 60:781-783.

Davies J.C. 1996. Study on the impact and control of diseases affecting the productivity of tethered goats, as compared to other methods of goat keeping in Morogoro region, Tanzania. Project report from the Department of Veterinary Medicine and Public Health, Sokoine University of Agriculture, Tanzania and Centre for Tropical Veterinary Medicine, Edinburgh University of Edinburgh Project Dates: January 1993 -March 1996.

Hansen, J. and Perry, B.1994. The epidemiology, diagnosis and control of helminth parasites of ruminants. International Livestock Centre for Africa, Addis Ababa. International Livestock Centre for Africa (1979) Small Ruminant Production in the Humid Tropics. ILCA Systems Study 3. ILCA, Addis Ababa, Ethiopia. pp. 40-76.
Kabasa, J.D., Opuda-Asibo, J. and Meulen, U. 2000. The effects of oral administration of polyethylene glycol on faecal helminth egg counts in pregnant goats grazed on browse containing condensed tannins. Tropical Animal Health and Production 32:73-86.

Kusiluka L. and Kambarage D. 2006. Diseases of small ruminants: A handbook of common diseases of sheep and goats in Sub-Saharan Africa. Lashari, M.H and Tasawar, Z. 2011. Prevalence of gastrointestinal parasites in sheep, Southern Punjab, Pakistan. Pakistan Veterinary Journal 31(4): 295-298.

MAAF (Ministry of Agriculture, Fisheries and Food), 1986. Manual of Veterinary Parasitological Laboratory Techniques. Reference Book 418. HSMO Books, London, 1986. pp. 159.

Magona, J.W. and Musisi, G. 1999. Bulletin Animal Health Production Africa 47:179-181.

Meingi, N., Gichigi, M.N. and Njoroge, G. K. 2001. Gastrointestinal nematode infection in sheep grazing on communal land in Nyandarua District of Central Kenya in repation to deworming practice. Bulletin of Animal Health Production (Africa) 49:153-161.

Nganga, C.J., Maingi, N., Kanyari, P.W.N. and Munyua, W.K. 2004. Gastro intestinal nematode infections in Dopper lambs in a semi-arid area of Kajiado District of Kenya. Bulletin of Animal Health and Production Africa 52:160-166.

Okwee-Acai, J., Ssajjakambwe, P., Okech, S.G., Agwai, B., Ekakoro, E. and Acon, J. 2010. Haemonchosis associated mortalities and treatment of severe anaemia by syringe infusion of blood in Boer goats in a model breeding 
farm in Lyantonde District, Uganda. African Journal of Animal and Biomedical Sciences 5(1): 80-84.

Waller, P.J. 2006. From discovery to development: Current industry perspectives for the development of novel methods of helminth control in livestock. 139(1-3):1-14.

Tasawar, Z.S., Ahmad, F., Lashari, M.H. and Hayat, C.S. 2010. Prevalence of Haemonchus contortus in sheep at Research Centre for Conservation of Sahiwal Cattle (RCCSC),
Jehangirabad, District Khanewal Punjab, Pakistan. Pakistan Journal of Zoology 42:735-739.

Vatta, A.F., Harrison, L.J.S., Krecek, R.C. and Pearson, R.A. 2004. Economic benefit of strategic anthelmintic treatment and urea-molasses block supplementation on Boer goats raised under extensive grazing conditions at Onderstepoort, Pretoria, South Africa. Paper presented at the 8th International Conference on Goats, 49 July 2004, Pretoria, South Africa. 